\title{
Em câmara lenta, de Renato Tapajós, 40 anos: autocrítica pública e sobrevivência
}

\author{
Maria Zilda Ferreira Cury ${ }^{1}$ \\ Rogério Silva Pereira²
}

\section{O livro}

Em câmara lenta foi escrito no (hoje já demolido) Presídio Tiradentes, na cidade de São Paulo, entre os anos de 1973 e 1974. O autor, Renato Tapajós, então com 30 anos, esteve preso ali, entre os anos 1969 e 1974 (Silva, 2006, p. 51), por integrar a Ala Vermelha, grupo maoísta de oposição clandestina à ditadura civil-militar brasileira (1964-1985).

O contexto em que o livro é escrito é o da repressão desencadeada pelo Ato Institucional $n^{\circ} 5$ (AI-5), de 1968, que culminou com a derrocada dos vários grupos clandestinos da esquerda armada, via expurgos de toda ordem - prisão, desaparecimentos, tortura e exílios voluntários e/ou forçados.

Com apenas duas edições, Em câmara lenta tem sido pouco lido pelo público ao longo dos anos. Contrasta, assim, por exemplo, com livros como $O$ que é isso companheiro, de Fernando Gabeira (sempre reeditado e com alcance atual de cerca de 100 edições) e Os carbonários, de Alfredo Sirkis (com vendagem mais modesta, é verdade, mas com um número de 20 edições, aproximadamente).

Notável, por contraste, é a fortuna crítica de Em câmara lenta. O livro é muito lido pela crítica, sobretudo na universidade. Contam-se às dezenas as dissertações e os artigos acadêmicos sobre ele. ${ }^{3}$

Como dito, o livro é escrito clandestinamente na prisão. Originalmente, o texto é manuscrito em papel comum; na sequência, copiado "em letras miúdas", em muitas folhas de papel de seda, que é dobrado até alcançar o tamanho de uma "pílula", impermeabilizado com fita adesiva e papel-celofane de cigarro e, aos poucos, levado para fora da

\footnotetext{
${ }^{1}$ Doutora em literatura brasileira e professora da Universidade Federal de Minas Gerais (UFMG), Belo Horizonte, MG, Brasil. (Dorcid.org/0000-0003-2945-7592. E-mail: mariazildacury@ gmail.com

${ }^{2}$ Doutor em literaturas de língua portuguesa e professor da Universidade Federal da Grande Dourados (UFGD), Dourados, MS, Brasil. (Dorcid.org/0000-0003-0195-030X. E-mail: rogeriopereira@ufgd.edu.br

${ }^{3}$ Ver os principais na bibliografia deste artigo.
} 
prisão, sob a língua, pelos pais do autor, depois das visitas que faziam ao filho. Posteriormente, usando-se lupa, o texto era lido e datilografado.

Em 1974, quando o autor é libertado, o livro está pronto para a publicação (Maués, 2008, p. 51; Silva, 2007, p. 52).

O texto é uma das primeiras expressões literárias da chamada "autocrítica", isto é, a crítica feita pelos próprios membros dos diferentes grupos de guerrilha à luta armada clandestina.

A Ala Vermelha é o grupo que primeiro implementa tal autocrítica, feita já de dentro do Presídio Tiradentes, por alguns de seus membros ali detidos. O grupo surge em 1966 a partir de uma dissidência do Partido Comunista do Brasil (PCdoB), e é reação às formas pacíficas de combate à ditadura militar propostas pelo $\mathrm{PCdoB}$; propugnava a guerra popular como forma de luta (Gorender, 1987).

Em documento produzido por volta de 1973, o grupo reconhece o reputado "erro fundamental" da esquerda armada, isto é, sua opção pela "luta armada imediata" contra o regime militar (Gorender, 1987, p. 204-205). Tapajós ajuda a redigir o documento, ao mesmo tempo que escreve Em câmara lenta (Silva, 2007, p. 52). Aspecto fundamental do livro, a autocrítica recebe ali uma abordagem que, também pioneiramente, articula procedimentos narrativos, posteriormente usados em outros livros, ficcionais ou não - escritos por ex-membros da luta armada contra o regime.

A obra é publicada em 1977. Inicialmente, o autor recorre a algumas editoras paulistanas, as quais recusam a publicação por temerem problemas com a censura. Enfim, o livro é aceito pela editora Alfa Omega. As capas de suas duas edições (1977 e 1979) trazem estampado o subtítulo "Romance". Com isso, acentua-se, até talvez como uma estratégia para driblar a censura, o caráter ficcional do texto. Dois meses depois do lançamento, o autor é preso e processado, e parte da edição confiscada pelo regime militar. $\mathrm{O}$ editor logrou distribuir a outra parte entre os livreiros, clandestinamente, e o livro pode então ser adquirido pelo público leitor.

Contudo, e diferentemente dos muitos livros posteriores que tratam do tema, o texto de Em câmara lenta está longe daquela típica linguagem do jornalismo da chamada imprensa nanica - característica presente, por exemplo, no já citado livro de Fernando Gabeira. O narrador de Em câmara lenta oferece um texto muitas vezes enigmático com, aparentemente, pouca adesão imediata ao referente; preferindo 
dar ao leitor, de modo fragmentário, a realidade que pretende representar. O texto parece um quebra-cabeça, um jogo, em que as partes de uma provável totalidade são dispostas em relativa desordem e com pouca articulação (Martins, 1985; Costa, 2012), convidando o leitor para a tarefa de montagem dos seus 63 fragmentos (Lasch, 2010, p. 280). A narrativa é constituída por um processo paratático, sobretudo no nível global da sua organização (Costa, 2012), podendo ser inserida no amplo espectro de romances experimentais do século $\mathrm{XX}$, muitos deles ancorados em estética semelhante de fragmentação (Dalcastagnè, 1996) - como, emblematicamente, o livro Zero de Ignácio de Loyola Brandão, publicado em 1974. Trata-se, igualmente, de obra inserida dentro de uma estética da denúncia e do protesto (Silverman, 1995, p. 429), como dezenas de outros livros, contemporâneos e posteriores.

Por outro lado, há momentos em que o texto de Em câmara lenta se mostra avesso à fragmentação e às meias palavras - sobretudo, em algumas cenas de violência, especialmente a de tortura exibida ao final (Tapajós, 1977). E, aqui, sublinhe-se que o texto também se mostra precursor. Muito do "realismo feroz" (Candido, 2000, p. 211) presente na ficção dos anos 1970 e posteriores encontra parentesco com as cenas de violência (tiroteios, tortura) que vemos em Em câmara lenta. Cite-se trecho para ilustrar:

Mas outro policial, que chegava na esquina no momento em que o primeiro caía, atirou-se ao chão, apontando seu fuzil FAL. Fernando atirou novamente, mas errou, surpreendido pelo movimento do policial. Este disparou uma rajada contínua; as balas atingiram Fernando no peito, uma ao lado da outra, abrindo na saída, um enorme rombo em suas costas (Tapajós, 1977, p. 106).

Em câmara lenta é a "primeira obra de ficção nacional a trabalhar o tema da luta guerrilheira dos anos 60 e 70 por um dos seus participantes" (Gorender, 1987, p. 205, itálico nosso). Nesse sentido, abre caminho para o chamado "memorialismo dos jovens" (Galvão, 2004 , p. 352). O autor/escritor ostenta a insígnia de alguém que "esteve lá", narrando com a legitimidade da testemunha.

Há em Em câmara lenta esforço grande por jogar luz sobre os espaços ocultos do mundo da clandestinidade, seja dos porões da tortura e das prisões, seja dos "aparelhos" e das células guerrilheiras, trazendo a público aquele mundo clandestino via linguagem do romance. Sobressai no livro um trabalho de "tradução", destinado a um "leitor-modelo" 
(Eco, 1986) que demanda saber do narrador os detalhes da guerrilha e da tortura e de outros aspectos da luta armada.

Desse modo, o escritor propõe desempenhar esse papel de "tradutor" entre dois mundos, a saber, o mundo privado, da guerrilha, da clandestinidade e dos porões da ditadura, e o mundo público - este, um novo mundo do qual o escritor é arauto e, ao mesmo tempo, um dos fundadores. Nessa função de tradutor, Tapajós é também pioneiro. Em 1977, data do lançamento do livro, está-se ainda há dois anos da Lei de Anistia e da extinção da Lei de Censura (ambas de 1979) - para contraste, confrontem-se as datas de publicação de Em câmara lenta com as dos anteriormente citados livros do memorialismo: Gabeira (em 1979) e Sirkis (em 1980), que só se farão publicar no período em que a citada legislação já havia sido sancionada, portanto em momento mais ameno da repressão.

Tendo se decidido por publicar seu livro anos antes desses sinais de abertura mais enfáticos, Tapajós lança alguns fundamentos novos para a ação pública de luta contra o regime militar. Na forma, opta claramente pelo ficcional e pelo mercado editorial como instrumento de luta. Enquanto, no conteúdo, põe de lado a luta armada, denunciando as práticas políticas dos grupos da esquerda clandestina.

Nessa linha, Tapajós fala, ao mesmo tempo, como um renegado e um convertido. Renegado: como alguém que nega a vida e as formas violentas e clandestinas de ação política, denunciando-as como formas ineficazes e/ou ilegítimas, tanto as ações do próprio regime como as da esquerda armada. Por outro lado, convertido: como aquele que se propõe a afirmar a ação política pública como alternativa àquelas formas de ação armada das quais participou - seu romance, verdadeira autocrítica pública, é em si mesmo a forma dessa ação.

\section{Autocrítica pública}

A autocrítica, como aqui é tratada, tem um sentido restrito. Trata-se do reconhecimento feito pelos grupos e militantes das esquerdas armadas, para si mesmos, dos erros cometidos no contexto de sua luta de oposição ao regime militar brasileiro. Ao mesmo tempo, a autocrítica é extensivamente usada no seio das guerrilhas do século XX, em várias partes do globo.

É possível pensar a autocrítica a partir do conceito de confissão tomado de Foucault (1988), a quem passamos a resenhar rapidamente. 
Em linhas gerais, a confissão se dá como "palavra requisitada, obrigada"; se desenvolve como "ritual de discurso que se desenrola numa relação de poder", com vistas à obtenção da verdade. Esta, por seu turno, é autenticada pelos obstáculos e resistências que são, presumivelmente, interpostos e superados no ato mesmo da confissão. Aquele que requer a confissão é mais que um confessor (como um padre, por exemplo), é, com efeito, uma instituição (como a Igreja Católica), que tem ampla ascendência sobre aquele que fala; sua função é ouvir e calar e/ou, no máximo, estimular com perguntas a fala daquele que confessa. Na narrativa da confissão, o sujeito da ação coincide com o sujeito que confessa, isto é, ali, alguém fala estritamente de suas próprias ações, algumas com recorrente teor de abjeção, sendo, muitas vezes, e até então, secretas. Apesar de ser o portador da fala, aquele que confessa não é o detentor do poder - o qual, sublinhe-se, encontra-se na posição oposta; é o confessor aquele que aglutina em si o poder. As consequências daquilo que a pessoa que confessa diz recaem, sobretudo, sobre ela mesma. Naturalizada no ocidente, originalmente assentada dentro do mundo católico, a confissão, na Modernidade, penetra vários ramos das práticas sociais - entre eles, as ciências e o direito - e se institucionaliza como principal mecanismo de produção da verdade. Por ser tão onipresente, frequentemente, não é percebida como ritual de coerção e de manifestação do poder, entendido em sua forma micrológica. Ao contrário, a confissão frequentemente é vista como momento mesmo de liberação; algo oposto a esse referido poder. Sendo assim, a iniciativa da confissão, muitas vezes, parte "espontaneamente" do sujeito que, independentemente das consequências externas, como as penas a ele infringidas, compreende-a como verdadeira catarse - se sentindo liberado e resgatado, depois de passar por ela, ainda que a seguir advenham punições, muitas vezes, as mais violentas.

Ao fazerem sua autocrítica interna, no seio da clandestinidade, os militantes realizavam literalmente uma confissão, sendo o grupo o confessor, com poder de vida e morte sobre o militante confidente. No contexto estritamente privado da vida da militância, os erros eram enunciados e avaliados à luz de uma ética de esquerda. Como na confissão católica ou jurídica, havia penitências e penas. Os erros, muitas vezes, eram de conhecimento exclusivo daquele que o cometia - 
que, contudo, tomava a iniciativa espontânea de confessá-los ao grupo. ${ }^{4}$ O alcance da autocrítica nunca ultrapassava o âmbito da oposição de esquerda. E, como se infere, o reconhecimento de erros não ficava restrito ao nível individual. Frações de grupos ou mesmo organizações inteiras fizeram sua autocrítica. Caso da Ala Vermelha, já mencionada.

Em câmara lenta, como se disse, é autocrítica que reconhece a luta armada como erro fundamental da esquerda. Entretanto, não se restringe ao horizonte das esquerdas. Destinado ao mercado editorial, para o público leitor de romances, moldado em termos ficcionais, tratase de confissão pública ou, em outras palavras, autocrítica realizada publicamente. A se reconhecer a função pública do gênero romance, a se reconhecer que o livro é romance, como diz seu subtítulo, Em câmara lenta figura como gênero novo, isto é, autocrítica voltada para amplificar uma esfera pública na qual, entre outros, deve-se discutir os acertos e erros da guerrilha armada em sua oposição à ditadura.

O típico leitor de romances, nos idos de 1977, é tomado como o novo destinatário da autocrítica enunciada pela esquerda. Ele é convidado, com alguma frequência, a ajudar o narrador na compreensão dos fatos narrados. Este, por sua vez, tendo estado nos espaços clandestinos e privados da luta armada, parece não ser capaz, ele sozinho, de dar sentido aos fatos que, contudo, só ele é capaz de narrar. Com efeito, há em Em câmara lenta a explicitação de uma desistência de entender o que, entretanto, o narrador não cessa de contar. De fato, este explicita que não consegue dar sentido, ou dispor numa ordem, certas peças do obsessivo "jogo" sobre o qual fala ao longo da narrativa. Diz o narrador: "O jogo de armar está aí para quem puder entendê-lo e encaixar todas as peças. Eu não posso mais - nenhuma coerência quando se destroem algumas peças" (Tapajós, 1977, p. 87, grifo nosso). "Eu não posso mais" sinalizará menos uma desistência do que uma solicitação de parceria. O parceiro convidado a montar o "jogo" será o leitor.

"O jogo de armar está aí para quem puder entendê-lo [...] eu não posso mais". Ao situar sua narrativa no âmbito do "aí", o narrador o faz também no âmbito do "tu" e do "você": os lugares propriamente do

\footnotetext{
${ }^{4}$ Alfredo Sirkis, em Os carbonários, dá boa mostra do que foi a autocrítica no Brasil no período referido. Também a ficção contemporânea brasileira apresenta, embora não como temática central, aspectos de autocrítica de militantes de esquerda da época da ditadura. Vejam-se, entre outros, os romances Amores exilados, de Godofredo de Oliveira Neto, Azul corvo, de Adriana Lisboa, K., relato de uma busca, de Bernardo Kucinski.
} 
leitor. Como se o narrador dissesse: "a narrativa está aí, para você". O dêitico "aí", na voz do narrador, repassa ao leitor a sua chance no jogo. O texto evoca um possível leitor capaz de dar sentido e articular o que está sendo narrado, tarefa aparentemente impossível para o narrador.

Há, pois, algo de precário (de fragmentário, de incompleto, de reconhecimento de incapacidade) na confissão proposta pelo narrador. O narrador de Em câmara lenta conta algo que sabe sobre si; algo que somente ele sabe. Evoca para si um parceiro, um confessor; alguém que irá ouvir o que confessa, alguém que possa entender o que narra. Se, como se viu, seu texto é um romance, ficcional e público, é fácil inferir quem é esse novo confessor: possivelmente alguém que tem a impessoalidade análoga do público genérico leitor de romances. Ao eleger esse público como destinatário de sua confissão, o autor livra-se ao mesmo tempo de dois confessores que, em outro momento, seriam os privilegiados. De um lado, o agente da ditadura, o policial ou o torturador; do outro, o companheiro de militância. Dentro do cárcere, com ambos "à disposição", o narrador prefere se dirigir a alguém impessoal que está fora dali: o público leitor de romances.

Assim, o livro transita da autocrítica privada à pública, reformulando o gênero autocrítica num de seus elementos essenciais, isto é, no que se refere a seu interlocutor. Não se está mais diante do companheiro conhecido, olhos nos olhos, ouvindo e falando. Agora, se está "diante" de uma massa ampla de leitores de romance, sem encará-los, sem suas interjeições, assentimentos, recusas etc.; sem ausculta, sem oitiva, sem voz. O registro deixa de ser oral e passa a ser escrito. Não se destina a um público restrito; ao contrário, visa a milhares de pessoas, diga-se, que são os leitores brasileiros daquele momento, familiarizados com os códigos da ficção romanesca, por meio dos quais Em câmara lenta se expressa.

Um último aspecto antes de avançar. Sobre a autocrítica feita pela Ala Vermelha na prisão, diz-se que se trata de "embrião de autocrítica" (Gorender, 1987, p. 204). O sentido para a palavra "embrião" talvez se relacione ao caráter pioneiro da iniciativa - algo que depois seria seguido por outras organizações. A se considerar a forte vinculação entre a autocrítica feita pela Ala Vermelha e a autocrítica em forma de romance levada a cabo na prisão por Tapajós (Silva, 2007, p. 52), não é ilícito dizer que o autor promove com seu Em câmara lenta um "esboço" daquilo que, em seguida, seria o formato de reinserção de muitos exguerrilheiros na pouco esboçada ordem pós-regime militar. Eis o 
formato: reconhecer, de modo público, via narrativa literária, que a luta armada foi o erro fundamental da esquerda.

\section{“Jogo de armar": ficção, ambiguidade e autocrítica}

Já se disse que Em câmara lenta se apresenta como jogo (Nunes, 2001; Martins, 1985). A narrativa, com efeito, é lúdica. E o sentido do jogo ali é múltiplo. Remete inicialmente ao ficcional. Com efeito, não se está ainda no universo do depoimento e do testemunho que, mais tarde, Gabeira e outros vão desenvolver. Não se está, pois, no terreno do texto referencial, parente do "romance reportagem" e da linguagem direta, colhida ao jornalismo que depois se tornou constituinte das narrativas do período. O mundo da tortura, dos aparelhos, da repressão e da guerrilha é aqui tratado por meio da montagem e da fragmentação que, àquela altura já fazia escola (Dalcastagnè, 1996) - sobretudo, no âmbito da literatura ficcional. Nesse sentido, é significativo o texto de Antonio Candido sobre Em câmara lenta, produzido quando da prisão do autor, para figurar como peça de defesa deste (Candido, 1978 apud Maués, 2008). O crítico desenvolve decisivamente seu argumento na direção de mostrar o romance como portador de uma lógica ficcional, baseada na ambiguidade de suas fórmulas (Candido, 1978 apud Maués, 2009). Nessa linha, a expressão “jogo de armar", recorrente no texto, se impõe como chave de leitura.

O título do livro é o mais evidente desses elementos ditos ambíguos, típicos da ficção, e merece destaque. "Em câmara lenta" remete a pelo menos três acepções dadas pelos dicionários à palavra "câmara". Dois desses sentidos remetem genericamente a "quarto", a "aposento no interior de uma casa". Daí derivam-se também os sentidos de "cela" e de "sala de tortura". A "câmara" seria então a cela em que o narrador estaria preso, no momento em que escreve/narra seu romance - por decorrência, a parede da cela seria, por assim dizer, a tela onde são projetados os fragmentos da memória do guerrilheiro, agora preso. Nessa parede também estarão as marcas da passagem de outros prisioneiros (como é comum nas celas em geral) que ali deixaram suas inscrições. Por outro lado, a "câmara" seria também a "sala de tortura", em que se dão momentos decisivos da narrativa. Nos dois casos, o sentido do título é amplificado pelo qualificativo "lenta". Ele faz referência à lenta passagem do tempo, seja no cárcere, seja durante a tortura. 
Um terceiro sentido de "câmara" remete ao equipamento, a câmara (ou câmera), usada para fotografar ou filmar. "Câmara lenta" refere-se à técnica de filmagem que permite que as cenas sejam vistas, durante a exibição, em "movimento lento". A expressão "em câmara lenta" aparece várias vezes ao longo do texto, abrindo sua cena central que vai sendo repetida e amplificada (Tapajós, 1977, p. 16, p. 25, p. 56, p. 167, entre outras).

Eis a primeira vez em que a expressão ocorre:

Como em câmara lenta: ela se voltou para trás. Sua mão descreveu um longo arco, em direção ao banco traseiro, mas interrompeu o gesto e desceu suavemente na abertura da bolsa [...] os dedos se fecharam sobre a coronha do revólver que estava na bolsa. E, num movimento único, corpo, rosto e braço giraram [...] $\mathrm{O}$ revólver disparou, clarão e estampido rompendo o silêncio (Tapajós, 1977, p. 16).

"Como em câmara lenta" é a expressão repetida ao longo do texto. $\mathrm{O}$ "como" sinaliza que se trata de um símile, uma figura de linguagem. Há diferença relevante com relação ao título. O título diz que se trata da própria "câmara lenta"; já no texto, a expressão sugere uma mediação: algo que se parece com a "câmara lenta". Que pode significar esse "como"? Algumas hipóteses: significa que a realidade ali representada tem algo de cinematográfico - mas não é cinema; que é algo que acontece lentamente, mais lentamente do que as ações "reais"; que é algo que deve ser oferecido aos poucos, como as mortes em certos filmes; que é algo que tem feição de coisa mediada, não diretamente experimentada, inscrevendo o texto no terreno da ficcionalidade, ambígua e irônica, entre outros sentidos.

Nessa linha, também ambígua é a expressão "jogo de armar", recorrente no romance (Tapajós, 1977, p. 63, p. 87, p. 96, p. 112, p. 113, p. 175). Ela se refere à sua estratégia narrativa, mas também ao "brinquedo" com que (os meninos) guerrilheiros se propõem jogar. À guerrilha é atribuído, assim, um novo sentido: o de brincadeira infantil: o de "jogo de (se) armar" (Lasch, 2010, p. 287), tomar (brincando, de brincadeira) armas para si.

Significativo, pois, é o trecho em que as personagens Ele, Ela e Marta conversam, amenamente, sobre as armas que têm em mãos (Tapajós, 1977, p. 61 e seguintes). Desde já, diga-se que há duas personagens no texto que não são nomeadas. Uma delas, o protagonista, que, vez ou outra, faz a função de narrador, tratado por "Ele". A outra, também protagonista, figura central da cena final de tortura do livro, tratada por 
"Ela". Assim, na referida cena, Ele, Ela e Marta estão num esconderijo. Marta limpa um revólver; Ele desmonta, limpa e remonta uma metralhadora; os três conversam. Marta o provoca: "Você trata essa metralhadora como se ela fosse uma criança". O diálogo prospera e, a partir daí, os personagens passam a falar não sobre aquelas armas que têm nas mãos, mas sobre as armas em geral, comparando os militantes que as usam a animais como o tigre, com seus músculos, a pantera, pronta para o salto, e a esculturas geométricas, com seus "traços precisos". As armas seriam funcionais, "eficientes", ou seriam meramente "belas"? As opiniões se opõem, mas sem conflitos sérios, tudo se dando como se fosse "brincadeira". Ao final da cena, a arma real aparece como brinquedo, como objeto do jogo.

Ele se concentrou na limpeza e montagem da metralhadora. Peça por peça, com uma gota de óleo, montava seu jogo de armar. Como em tudo, ele sabia que ali também o mais importante era organizar corretamente as peças do jogo de armar (Tapajós, 1977, p. 63, grifo nosso).

Significativo que a expressão "jogo de armar" apareça duas vezes num trecho em que a arma figura como elemento estético e lúdico, e não como elemento funcional, como instrumento para ferir e matar. Eis o guerrilheiro cuidando de sua arma, como o faz qualquer soldado, mas também como se esta fosse um brinquedo querido.

Pode-se pensar toda a cena como metonímia da própria guerrilha: é a guerrilha brincando de fazer guerra. A cena é forma de colocar em questão o profissionalismo dos guerrilheiros e sua efetiva maturidade. Veja-se, ainda, outro exemplo. "Na parede da cela alguém havia escrito com letras pequenas e ligeiramente tremidas: "uma multidão de crianças/que só queria brincar/Portando espadas de papel/perdeu-se no tempo" (Tapajós, 1977, p. 92).

Aqui, outro lampejo de autocrítica que parece descrever o típico guerrilheiro como imaturo. Arrisque-se um sentido. "Alguém", talvez um preso político, como o próprio Tapajós, escreveu os versos em letras "pequenas" e "tremidas" (infantis, trêmulas? Fragilizadas pela tortura?). Estaria esse alguém entre a multidão de "crianças", muitas delas presos políticos ali, no presídio Tiradentes? Estaria esse alguém entre os jovens guerrilheiros que lutaram contra o regime militar? Nessa linha, o narrador se reconheceria nessa multidão de crianças também? A fragilidade das armas, "espadas de papel", seriam correlatas às "belas armas" a que se 
aludiu mais acima? E esse "perder-se no tempo" - seria um eufemismo para a morte pura e simples ou para a inutilidade da luta?

Outro aspecto que merece destaque. A personagem Marta cumpre importante função retórica. É ela quem se esforça por reiterar a Ele e a Ela a importância utilitária e instrumental das armas; é ela quem sublinha a importância das pessoas em contraste com as armas; é ela, enfim, quem aponta certa ingenuidade no personagem Ele, que insiste em ver a beleza das armas. Pode-se atribuir um sentido ao nome "Marta" dentro da economia ambígua de Em câmara lenta: "Marta" (que vem de Marte, deus da guerra na mitologia romana) é coerente com a função dada no trecho à personagem. Ali, ela cumpre papel arquetípico, o de relembrar a importância instrumental da arma numa guerra - em contraste com a possível beleza que esta poderia exibir. Um chamamento ao realismo e ao pragmatismo. Marta cumprirá com frequência essa função de convocar para a guerra (Tapajós, 1977, p. 120 e outras).

Em câmara lenta aborda o problema e traça suas linhas mestras. As armas são belas ou são úteis, são brinquedos ou são "de verdade"? Os jovens guerrilheiros desperdiçaram suas vidas? Os meninos guerrilheiros brincaram demais com as armas? A guerrilha foi uma iniciativa infantil; brincadeira de crianças desavisadas numa guerra de verdade contra um Estado profissional?

A longa análise ganha sentido mais amplo quando se explicita uma importante intenção do autor no texto introdutório do livro. Em "O autor por ele mesmo", cerca de dez páginas, escritas entre aspas, Tapajós fala explicitamente em "autocrítica" e em "balanço" (Tapajós, 1977, p. X).

Com efeito, a autocrítica atravessa o texto e o divide em duas dimensões. Por assim dizer, o texto traça a baliza narrativa que demarca o lugar onde a autocrítica é feita. Ela é estruturada para marcar distâncias, ao mesmo tempo que, paradoxalmente, estabelece laços: entre o passado narrado e o presente da narração, entre a ingenuidade irrefletida e a maturidade reflexiva; entre o pensamento e a ação pura e simples; entre a épica guerrilheira e a nada épica vida pós-derrota; entre o cárcere e a liberdade; entre os sobreviventes e os mortos. E é estruturada para marcar uma ruptura, uma transição.

"Hoje eu olho para essa parede em minha frente, a mesma parede de todos os dias, onde desfilam os rostos conhecidos e ela me devolve, com suas manchas, os fragmentos do passado. Fragmentos: as peças do jogo de armar" (Tapajós, 1977, p. 112, grifo nosso). Esta passagem é 
emblemática quanto ao lugar e ao tempo em que o texto de Em câmara lenta é enunciado, e eloquente quanto ao seu enunciador. O leitor está diante de uma fala do narrador; este enuncia simultaneamente no "hoje" e de dentro do cárcere. Sua matéria são os elementos dispersos da memória que, "hoje", dentro do limitado espaço do cárcere, se dão ao conhecimento de seus pensamentos e de seu discurso. São, de fato, seus pensamentos o que se lê ali, é discurso direto, mas não é fala; é fluxo de consciência. São os elementos do passado, seus rostos e fatos, que, por assim dizer, se projetam na parede da cela. São os mesmos fragmentos do jogo de armar, aludido mais acima, para o qual talvez não haja solução. É, enfim, a câmara lenta de "todos os dias" - câmara lenta, nos vários sentidos atribuídos à expressão, situação distópica de encarceramento do sujeito que narra.

Notável, contudo, é o não dito que se pode inferir desse trecho. Ao se representar no texto, o autor/narrador o faz figurando-se em radical solidão. Com efeito, onde estão os demais companheiros? Onde está, no trecho (e, por decorrência, no livro todo), a vívida comunhão coletiva da cela em que, de fato, esteve Tapajós no Presídio Tiradentes? O típico cárcere brasileiro (e o cárcere dos presos políticos também) é coletivo. $\mathrm{O}$ documento de autocrítica escrito de modo coletivo pela Ala Vermelha é expressão dessa vida comunitária do cárcere - o próprio Tapajós dá pistas sobre isso (Silva, 2006). Notável solidão. O fluxo de consciência, fórmula romanesca modernista da solidão silenciosa, e as imagens fragmentadas da narrativa são já o esforço de representação do afastamento do militante em relação à coletividade de origem, o grupo de ex-guerrilheiros presos, com quem, entretanto, Tapajós compartilha a cela.

O trecho é, enfim, uma vívida representação da imobilidade e do isolamento, reflexivos e silenciosos do ex-guerrilheiro, agora preso, que, após intenso período de ação, se põe a fazer autocrítica e balanço de sua vida. Sua imobilidade é oposta à típica ação, muitas vezes irrefletida, representada em vários momentos do livro, em que os personagens individualmente lutam contra as forças da repressão, não raro sendo abatidos. E seu isolamento é também o oposto do típico comunitarismo (às vezes, conflituoso) que reinava dentro das organizações guerrilheiras de então.

Trata-se mais do que autocrítica e balanço, representa o espaço e o tempo mesmos em que a autocrítica e o balanço se dão: a câmara-cela e o tempo do "hoje" repletos das memórias da guerrilha, com seus dias 
lentos e introspectivos. Representa literária e ficcionalmente a ruptura em relação à vida comunitária da guerrilha. Ao lado disso, representa literária e ficcionalmente o isolamento radical a que o escritor/narrador quer se submeter nessa nova fase. Eis então um narrador que, efetivamente, quase não tem corpo; que é pura consciência voltada, com recorrência quase doentia, para o passado e para si mesma. Na narrativa, as fronteiras entre passado e presente são delineadas.

\section{Dois sobreviventes e um terceiro}

Insistimos anteriormente nas balizas que demarcam a relação entre passado da ação narrada e presente da narração. Agora é preciso alinhavar os vínculos que o próprio texto constrói entre um e outro. Esse vínculo compõe a indumentária do que chamaremos de sobrevivente.

No romance Em câmara lenta, o leitor vê figurados três tipos de sobreviventes. O herói suicida, sobrevivente provisório; o desertor, abjeta figura (ao menos para a narrativa); e o próprio narrador do romance, que conta seu passado a partir da cela.

O herói suicida, sobrevivente provisório, é o primeiro. É sobretudo o personagem Ele quem permite ao leitor, a partir de sua subjetividade, a melhor aproximação desse primeiro tipo de sobrevivente. Em câmara lenta recria para o leitor a tensão dentro da consciência do referido personagem quanto à eficiência da luta armada. $\mathrm{O}$ personagem reflete sobre sua permanência na luta armada e quanto ao preço que ele e os demais estão pagando. Sua conviç̧ão é férrea, mas sua posição é singular: ele sabe que a luta é inútil, contudo, vê profunda necessidade em nela permanecer.

As reflexões do personagem tentam dar ao leitor uma visão daquilo que ia no pensamento de certo tipo de guerrilheiro nos exatos momentos finais de derrocada da guerrilha. Nessa etapa, parece haver já uma certeza da inutilidade da continuidade da luta contra o vitorioso regime militar (uma referência histórica seria os idos de 1972 e 1973, quando, de fato, a guerrilha sofreu suas principais baixas e se encaminha para o ocaso). O que mais surpreende: a iminência da derrota não parece deter o personagem, ao contrário, há nele um imperioso e contraditório compromisso, o de que a luta precisa continuar - em função, sobretudo, dos companheiros já mortos. Nos pensamentos do personagem Ele, uma forte tensão se evidencia: "Afirmar de uma vez para sempre aquilo em que não se acredita mais. 
Nenhuma outra atitude é possível - negar como? Negar é negar a si mesmo, é negar o sacrifício, é negar o sangue" (Tapajós, 2016, p. 101, grifo nosso). Eis a contradição, nas palavras em itálico: afirmar até o fim uma luta que já não tem perspectiva de vitória; negar essa mesma luta, negando o sacrifício já feito pelos companheiros mortos.

Como é que eu vou recuar com todos os olhos, com todos os rostos, com todas as lembranças dos mortos olhando para mim e os meus companheiros, os que vão morrer continuando? Como é que eu posso desertar da luta inútil quando por ela morreram tantos [...] desertar é largar os outros no fogo e procurar um caminho certo quando os outros estão morrendo. Por que o meu compromisso é com os mortos e com os que vão morrer (Tapajós, 1977, p. 160, grifo nosso).

Nesse ponto, eis uma virada importante da guerrilha que Em câmara lenta registra: já não se luta mais pela liberdade, pelo socialismo, contra a opressão do regime militar; luta-se até o fim, isto é, até a morte, porque é preciso honrar o sangue dos companheiros já mortos. Épica luta pela honra.

Há um segundo tipo de sobrevivente. Trata-se do desertor. Sua condição é a da abjeção: "Sobreviver como um verme, como uma lesma, como um parasita esgotado. Conheço aqueles que tiveram medo e caíram fora, todos têm o olhar culpado, o mesmo gesto esquivo" (Tapajós, 1977, p. 101).

À certa altura da narrativa, o personagem Ele se encontra com um ex-guerrilheiro, um desertor. $\mathrm{O}$ encontro é fortuito, numa das ruas da cidade do Rio de Janeiro. No desertor, o olhar culpado e os gestos esquivos permitem entrever a abjeção aludida. Os trechos a seguir, retirados de uma longa cena, põem em diálogo o personagem Ele e Ricardo, o aludido desertor, agora, um hippie. Apesar de tudo, o encontro expõe certa dose de ambiguidade. Diz Ricardo: “Eu assumo, tá, e grito para quem quiser saber: eu, Ricardo, sou um pequenoburguês medroso, desesperado e sem perspectiva" (Tapajós, 1977, p. 134). Por seu turno, o personagem Ele fala reconhecendo o isolamento das organizações guerrilheiras em relação ao resto da sociedade: "O que sentia era como se a organização fosse um outro planeta, sem nenhum ponto de contato com aquilo ali. Alguém estava fora da realidade, alguém estava num outro mundo" (Tapajós, 1977, p. 134-135). Em todo caso, a cena expõe o contraste entre os dois mundos, o do herói revolucionário, já sem convicção, mas submergido na luta, e o do 
desertor acovardado e sem perspectiva, que tomou a decisão de sobreviver, ainda que de modo culpado.

Por seu turno, o terceiro sobrevivente é o próprio autor/narrador de Em câmara lenta, alguém que, depois da captura e da tortura, está na prisão às voltas justamente com seus mortos.

Com efeito, Em câmara lenta é texto que configura pioneiramente seu narrador como um sobrevivente - nesse sentido, um sobrevivente muito específico. Um viés produtivo para se pensar o sobrevivente é o de associálo à condição de testemunha. A seguir, apoiados em Agamben (2008), definimos "sobrevivente" a fim de pensar o narrador de Em câmara lenta.

O termo "supertes", "testemunha" em latim, define a testemunha como aquele que viveu algo do começo ao fim; aquele que atravessou até o fim um ou mais eventos, e pode, por isso, dar testemunho disso (Agamben, 2008, p. 27). Na perspectiva de Agamben, a testemunha se inscreve em seu relato como alguém que "decide" sobreviver eventualmente para relatar o que viveu; ela carrega consigo o sentimento de ser, como sobrevivente, um privilegiado em relação àqueles que "tocaram o fundo", que morreram ou foram silenciados. Além disso, ela expressa sua disposição para narrar não só seu destino, mas também o daqueles que, com ela, compartilharam certos eventos, inclusive as pessoas já mortas; expressa também a condição daquele que quer falar por outrem ou dar voz a este (Agamben, 2008, p. 42-43).

Agamben se baseia, entre outras, nas narrativas de Primo Levi sobre as vivências em campos de concentração nazistas, durante a Segunda Guerra Mundial. Com efeito, Levi define os sobreviventes como aqueles que, por prevaricação, por habilidade ou por sorte, "não tocaram o fundo" (Agamben, 2008, p. 42-43). Levi enlaça seu destino ao daqueles que, no campo de concentração, morreram ou perderam parcial ou definitivamente sua humanidade. Guardadas as proporções é possível pensar no narrador de Em câmara lenta como sendo um sobrevivente aos moldes de Levi, isto é, como alguém que está par ao par com (seus) mortos.

Ser guerrilheiro e estar na cela em 1974 é, via de regra, ter sobrevivido, e é ser testemunha das mortes de muitos companheiros. O regime militar havia praticamente consumado o desmantelamento das esquerdas armadas naquele ano. O resultado: centenas de mortos e desaparecidos, centenas de exilados, centenas de presos. O narrador de Em câmara lenta 
havia escapado da morte e acaba também por enlaçar seu destino ao dos mortos sobre os quais dá testemunho em seu texto.

Na cela, como se viu, o narrador se constrói como sobrevivente em relação aos personagens da narrativa, seus companheiros, todos mortos. Marta, seu companheiro Sérgio, Lúcia, Fernando, Ele (entre outros) todos metralhados em ação. E a personagem Ela, morta sob tortura, com o crânio esmagado. Construir-se como sobrevivente em Em câmara lenta é ter aguda consciência das mortes dos companheiros; é construir-se como sobrevivente em função dessas mortes.

O narrador sabe os detalhes das mortes, ele as conta como se estivesse lá, no momento em que acontecem. Assim, por exemplo, no final da narrativa, quando o personagem Ele morre, lá está o narrador permitindo que o próprio personagem narre a ação em monólogo interior - e lá está o narrador para narrar, ele mesmo, em detalhes, o momento em que o personagem é metralhado (Tapajós, 1977, p. 176). Nesse fragmento, o último do romance, a realidade externa e a interioridade do personagem são encenadas para o leitor. Como no conceito proposto por Agamben, o narrador de Em câmara lenta se constrói como "supertes", isto é, como testemunha que viveu, par a par, a experiência junto com aquele morto.

Há, por outro lado, momentos em que o personagem Ele não está presente (pois já está morto), mas o narrador está presente, in loco, para testemunhar e contar em detalhes o que se passa. É o caso da morte, sob tortura, da personagem Ela.

Furiosos, os policiais tiraram-na do pau-de-arara, jogaram-na ao chão. Um deles enfiou na cabeça dela a coroa-de-cristo: um anel de metal com parafusos que o faziam diminuir de diâmetro. Eles esperaram que ela voltasse a si e disseram-lhe que se não começasse a falar, iria morrer lentamente. Ela nada disse e seus olhos já estavam baços. O policial começou a apertar os parafusos e a dor a atravessou, uma dor que dominou tudo, apagou tudo e latejou sozinha em todo o universo como uma imensa bola de fogo. Ele continuou a apertar os parafusos e um dos olhos dela saltou para fora da órbita devido à pressão no crânio. Quando os ossos do crânio estalaram e afundaram, ela já havia perdido a consciência, deslizando para a morte com o cérebro esmagado lentamente (Tapajós, 1977, 172, grifo nosso). 
No fragmento, já tão clássico quanto polêmico, misturam-se sumário e cena para contar a história da captura e tortura da personagem. Depois de matar um policial numa blitz e fugir de um cerco policial, a personagem é capturada sob intensa violência por agentes do regime militar. Violência que ela, como pode, tenta revidar. Em seguida é submetida à tortura, espancada, desnudada, baleada, pendurada no pau-de-arara e, por fim, morta. Note-se aqui o esforço do narrador para estar presente - para ser testemunha. A personagem resiste a tudo altiva e calada, sem qualquer confissão, com poucas manifestações de dor: "Ela nada disse" e "a dor a atravessou, uma dor que dominou tudo". No primeiro trecho, a última reiteração do silêncio da personagem violentada, mas corajosa, ela nada confessa aos torturadores. No segundo trecho, o narrador parece saber os detalhes da dor que a personagem sente: "uma dor que dominou tudo" (e aqui, diga-se de passagem, o leitor não está isento de ver na morte da personagem uma alegoria da morte de toda a luta revolucionária contra o regime militar).

O narrador, assim, está com alguma liberdade, às vezes onisciente, às vezes onipresente, próximo aos mortos, quase uma dezena deles, no momento de suas respectivas mortes: narradas em detalhes, em slow motion, em "câmera/câmara lenta". Em qualquer caso, mortes em que aquele que narra resta como sobrevivente.

Em outros momentos, contudo, a fórmula deve ser ajustada para nela caber a realidade. Eles morreram para que o narrador sobrevivesse. Tais mortes são espécie de sacrifício heroico feito aos companheiros vivos, à organização e, no limite, à revolução. Assim, por exemplo, as mortes de Marta (Tapajós, 1977, p. 24) e de Fernando (Tapajós, 1977, p. 106) parecem propiciar a fuga e, portanto, a sobrevivência de outrem - inclusive a do narrador.

Eis então o narrador de Em câmara lenta, uma pura consciência, hipertrofiada, que se sabe sobrevivente, um terceiro sobrevivente que é configurado via narrativa.

Diga-se, para fim de distinção, que esse sobrevivente não é nem o desertor, descrito como abjeto; nem o herói abnegado, descrito como o iminente suicida que continua a luta armada, não pelos ideais de emancipação da guerrilha, e sim (estranhamente) para honrar os companheiros já mortos.

Esse sobrevivente constituído pela narrativa de Em câmara lenta é novo. Capturado, torturado e prisioneiro sentenciado, não descuida de 
seus mortos e de suas mortes. Ainda que vivo, não tem uma vida própria para zelar - senão mortes alheias violentas com as quais deve conviver. A afirmação de Levi, reproduzida na citação de Agamben, ressoa. Por que justamente ele, entre tantos, está vivo? Por prevaricação, por sorte ou por habilidade, ele transcendeu as alternativas que, em seu tempo, lhe foram dadas: ser o abjeto desertor; ser o heroico suicida que sobrevive provisoriamente. Entre uma e outra, uma terceira: a daquele que denuncia a ingenuidade da luta armada e a violência extrema do regime militar ditatorial. Par a par com seus mortos.

Em câmara lenta intenta ser jogo de armar, não um xadrez. Mas, nesse jogo, Tapajós configura-se como um peão. Postado à frente, espécie de vanguarda, pioneiro, se constitui novo soldado, de novo combate. Em sua autocrítica, se despe do passado; como sobrevivente, se enlaça a ele. O combate: a vida pública brasileira no pós-ditadura.

\section{Referências}

AGAMBEN, Giorgio (2008). O que resta de Auschwitz: o arquivo e a testemunha. Tradução de Selvino J. Assmann. São Paulo: Boitempo.

BRANDÃO, Ignácio de Loyola (1986). Zero. São Paulo: Clube do Livro.

CANDIDO, Antonio (2000). A nova narrativa. In: CANDIDO, Antonio. A educação pela noite e outros ensaios. São Paulo: Ática. p. 199-215.

COSTA, Carlos Augusto Carneiro (2012). Realismo em Adorno e Lukács: o caso "Em câmara lenta", de Renato Tapajós. Estudos de literatura brasileira contemporânea, Brasília, n. 39, p. 19-36, jan./jun.

DALCASTAGNÉ, Regina (1996). O espaço da dor. O regime de 64 no romance brasileiro. Brasília: Editora da UnB.

ECO, Umberto (1986). Lector in fabula. Tradução de Attílio Cancian. São Paulo: Perspectiva.

FOUCAULT, Michel (1988). Scientia sexualis. In: FOUCAULT, Michel. História da sexualidade I: a vontade de saber. Tradução de Maria Thereza da Costa Albuquerque e J. A. Builhon Albuquerque. Rio de Janeiro: Graal. p. 51-71.

GABEIRA, Fernando (1981). O que e isso, companheiro? Rio de janeiro: Codecri.

GALVÃO, Walnice Nogueira (2005). A voga do biografismo nativo. Estudos Avançados, São Paulo, v. 19, n. 55, p. 351-366. 
GORENDER, Jacob (1987). Combate nas trevas: a esquerda brasileira - Das ilusões perdidas à luta armada. São Paulo: Ática.

LASCH, Markus (2010). Em câmara lenta: representações do trauma no romance de Renato Tapajós. Remate de males, Campinas, v. 30, n. 2, p. 277-291, jul./dez.

MARTINS, Mercedes Bertoli (1985). Em câmara lenta, um jogo de armar. Dissertação (Mestrado em Letras) - Universidade Federal de Santa Catarina, Florianópolis.

MAUÉS, Eloísa Aragão (2008). Em câmera lenta, de Renato Tapajós: a história do livro, experiência histórica da repressão e narrativa literária. Dissertação (Mestrado em História Social) - Universidade de São Paulo, São Paulo.

MAUÉS, Eloísa Aragão (2009). Defesa notável. Teoria e debate, São Paulo, n. 74. p.35-37, nov./dez.

NUNES. Lucimeire Viana (2001). O discurso anti-heróico no romance Em câmara lenta. Revista de Letras, Fortaleza, v. 1, n. 23, p. 33-37, jan./dez.

SILVA, Mário Augusto Medeiros da (2006). Prelúdios E noturnos: ficções, revisões e trajetórias de um projeto político. Dissertação (Mestrado em Sociologia) - Universidade Estadual de Campinas, Campinas.

SILVERMAN, Malcolm (1995). Protesto e o novo romance brasileiro. São Carlos: Editora da UFSCar.

SIRKIS, Alfredo (2014). Os carbonários. Rio de Janeiro: TIX.

TAPAJÓS, Renato (1977). Em câmara lenta. São Paulo: Alfa Omega.

Recebido em 30 de maio de 2017.

Aprovado em 4 de novembro de 2017.

resumo/abstract/resumen

\section{Em câmara lenta, de Renato Tapajós, 40 anos: autocrítica pública e sobrevivência}

Maria Zilda Ferreira Cury

Rogério Silva Pereira

Em câmara lenta, romance de 1977, é narrativa pioneira em vários sentidos. Nele estão claramente definidos os temas da autocrítica e da sobrevivência aspectos que, posteriormente, irão atravessar as várias narrativas, ficcionais 
ou memorialísticas, dos militantes de esquerda e ex-guerrilheiros, que se propõem contar suas experiências sobre o auge da repressão do regime militar brasileiro (1964-1985). O presente artigo, assim, lê o romance a partir dos conceitos de autocrítica (valendo-se do conceito de confissão, Foucault, 1988) e sobrevivência (Agamben, 2008).

Palavras-chave: Em câmara lenta, regime militar brasileiro, romance, confissão, sobrevivência.

\section{Em câmara lenta, by Renato Tapajós, 40 years: public self-criticism and survival}

Maria Zilda Ferreira Cury

Rogério Silva Pereira

Em câmara lenta, a 1977 novel, is a pioneer narrative in several ways. In it, the themes of self-criticism and survival are clearly defined - aspects that will later appear in several fictional or memorialist narratives of left-wing and former guerrilla militants who intend to tell their experiences with the repression by Brazil's military regime (1964-1985). This article analyzes the novel through the point of view of self-criticism (using the concept of confession, Foucault, 1988) and survival (Agamben, 2008).

Keywords: Em câmara lenta, Brazilian military regime, novel, confession, survival.

\section{Em câmara lenta, de Renato Tapajós, 40 años: autocrítica pública y supervivencia}

Maria Zilda Ferreira Cury

Rogério Silva Pereira

Em câmara lenta, novela de 1977, es una narrativa pionera en varios sentidos. En ella, los temas de autocrítica y supervivencia están claramente definidos, aspectos que luego atravesarán numerosas narraciones ficticias o memorialísticas de izquierdistas y ex militantes guerrilleros que pretenden contar sus vivencias con la represión del régimen militar brasileño (1964 1985). Este artículo analiza la novela desde el punto de vista de la autocrítica (utilizando el concepto de confesión, Foucault, 1988) y la supervivencia (Agamben, 2008).

Palabras clave: Em câmara lenta, régimen militar brasileño, romance, confesión, supervivencia. 